\title{
Administrators’ Lessons Learned: Considerations in Establishing Demonstration Classrooms
}

\author{
Tiffany L. Gallagher, Brock University and
}

\section{Author Note}

Arlene L. Grierson, Nipissing University

Findings from this research were presented at the Annual Convention of the International Reading Association (IRA). Atlanta, GA and the Annual Meeting of the Canadian Society for the Study of Education (CSSE). Saskatoon, SK. As well this paper draws on findings that were included in a report that was prepared for the Literacy and Numeracy Secretariat (Ministry of Education of Ontario)

Correspondence concerning this article should be addressed to Tiffany L. Gallagher through email: tiffany.gallagher@brocku.ca or Arlene L. Grierson through email: arleneg@nipissingu.ca

\begin{abstract}
This paper presents the perspectives of some administrators whose school sites hosted demonstration classrooms that were implemented as part of a board-wide professional development initiative. Administrators highlighted the challenges of balancing the competing needs of their school system with those of their individual school communities and identified: (a) the need for advance planning; (b) the importance of consistency and communication; and (c) the complexities of acknowledging the dual roles and responsibilities held by demonstration classroom teachers. Demonstration classroom professional development programs may hold the potential to enhance teachers' knowledge and skills. However, this study found that effective implementation of such programs requires skilled administrative collaboration and coordination.
\end{abstract}

Keywords: educational leadership; professional development; demonstration classrooms 


\section{Administrators' Lessons Learned: Considerations in Establishing Demonstration Classrooms}

There is general agreement that effective teacher professional development is required in order to improve student achievement (Guskey, 2002). In order to maximize the potential for sustainable improvement in students' educational outcomes and support systemic long-term change, teachers' professional development opportunities should build school capacity (Youngs, 2001). Newmann, King, and Youngs (2000) defined school capacity as the knowledge, skills, and dispositions of individual teachers, the administrative leadership, the strength of the school's professional community, the extent to which programs are coherent, and the quality of resources. Effective leadership is of pivotal importance in all aspects of school capacity building, particularly in supporting teachers' professional growth (Elmore, 2004; Fullan, 2006a).

The potential for increasing teachers' expertise may be augmented by focusing on program coherence through the creation of an integrated web of related professional development opportunities, designed to provide consistent provincial, district, and school-based program messages, while at the same time meeting teachers' diverse individual needs (Guskey, 2003; Youngs, 2001). The administrative leader is the binding agent for these components of school capacity building that collectively support teachers' professional growth and ultimately contribute to improved student achievement (Fullan, 2006b; Youngs, 2001).

This paper profiles the perspectives of elementary school administrators who contributed to capacity building by hosting within their individual school sites, a demonstration classroom provided as part of a district-wide professional learning initiative. Teachers from throughout the school board were encouraged to observe exemplary teaching practices in action in one of four grade-specific demonstration classrooms, each of which was located in a different school site within the district. The general success of the demonstration classroom initiative in enhancing observing teacher participants' knowledge and skills has been documented (Grierson \& Gallagher, 2009). This study extends these understandings by highlighting the administrative leadership and dedication that was required to negotiate the tensions created by attempting to simultaneously meet the, at times, competing needs of the school system and those of the individual school sites hosting the demonstration classrooms.

In this paper, we first provide an overview of the literature detailing the vital role of administrative leadership in supporting teachers' professional learning. We next outline the rationale for the study followed by our methodology, which includes detailed descriptions of the participants and the demonstration classroom initiative. In discussing the findings that reveal the complexities of administrative leadership of site-based, system-wide professional learning initiatives, we highlight the attributes of effective leaders exhibited by the administrators of this demonstration classroom program. The lessons learned through this study reveal how skilled administrative collaboration, coordination, and flexibility were essential to effective implementation of this professional learning initiative for elementary school teachers. These findings may provide direction for others interested in implementing site-based, system-wide teacher professional learning initiatives.

\section{Administrative Leadership and Teachers' Professional Learning}

Administrators' active leadership is integral to engaging teachers in professional learning opportunities (Matsumara, Sartoris, Bickel, \& Garnier, 2009). When administrators validate the importance of professional learning and the expertise of those selected as mentors and 
professional development facilitators, teachers' receptivity to critically examining and where necessary modifying their practices is enhanced (Matsumara et al., 2009). Additionally, when administrators reduce the barriers to school-based professional learning (e.g., provide teacher release time, space to collaborate) an implicit message is sent to teachers that the activities they are engaging in are valuable (Mangin, 2007). Furthermore, administrators leading by example and actively participating in professional learning can enhance teachers' ongoing willingness to devote their time and energy to reiteratively refining their practices (Matsumara et al., 2009).

Building capacity for sustainable changes in teachers' practices is a time consuming process that requires teachers to continuously build on their knowledge base and reflect on their practices, while being supported by opportunities for collaboration, mentoring, and dialogue with colleagues (Dufour \& Eaker, 1998; Lyons \& Pinnell, 2001; Walpole \& McKenna, 2004). Collaboration with colleagues, in particular, has been shown to enhance teachers' self-efficacy and support their abilities to modify their programs (Butler, Lauscher, Javis-Selinger, \& Beckingham, 2004; Cochran-Smith \& Lytle, 1999; Dufour \& Eaker, 1998). Suggested formats for such constructive experiences have included small group professional learning communities that engage in collaborative reflective exploration of common issues or problems in attempts to improve professional practice (Dufour \& Eaker, 1998; Fullan, Hill, \& Crevola, 2006).

While school-based professional learning communities are important, substantive collaborative cultures are ones that build the capacity for continuous improvement within both individual schools and within the school district and system at large (Dufour \& Eaker, 1998; Fullan, 2006a). In order to transform and improve schools, a school board must be prepared to embrace systemic change (Ferguson, Kozleski, \& Smith, 2001). Given the magnitude of systemic change, schools need to collegially interact with each other in order to demonstrate what they are doing and learn from each other. This process is coined "lateral capacity building" and it contributes to school-wide improvement (Fullan, 2006a). Dedicated knowledgeable teachers and effective leadership are crucial for both school-wide and system-wide improvement (Fullan, 2006a; Youngs, 2001).

To contribute to lateral capacity building, teachers need opportunities to engage in continuous professional learning, directed at their own classroom practices (Elmore, 2004). More specifically, teachers benefit from opportunities to observe others teaching and have others observe their teaching (Walpole \& McKenna, 2004). In this way, teachers are able to identify their own challenges and the challenges that others face in their practice within similar contexts (Elmore, 2004). Overall, teachers must be receptive to embarking on instructional improvements in order to facilitate their own learning and the collective learning of their teaching colleagues (Fullan, 2006a).

For teachers to build on their knowledge base and reflect on their practices, they also require opportunities to debrief with each other and a mentor (Lyons \& Pinnell, 2001; Walpole \& McKenna, 2004). Demonstration classrooms have been recommended as observation sites for teachers to witness their peers modelling effective instructional strategies that contribute to student learning and engagement (Ontario Ministry of Education, 2005; Sparks \& LoucksHorsley, 1990). Post-observation, educators then consult with the practising mentor teacher, after which they attempt to refine their own instructional practices by implementing those modelled (Poglinco, Bach, Hovde, Rosenblum, Saunders \& Supovitz, 2003). 
Demonstration classrooms have been suggested as a vehicle to provide teachers with vicarious experiences intended to enhance their willingness and abilities to embrace change and enhance their classroom practices (Ministry of Education of Ontario, 2005; Sparks \& LoucksHorsley, 1990). However, the experiences of administrative leaders involved in the implementation of demonstration classroom, professional learning initiatives have not been investigated.

\section{Research Rationale}

Recently, a moderate-sized southern Ontario school board implemented a demonstration classroom professional development program. This initiative was implemented in four individual school sites. Each school hosted one grade-specific demonstration classroom that was intended to enhance the abilities of elementary teachers throughout the school district to implement evidence-based literacy and numeracy practices. The effectiveness of this professional development initiative in enhancing participating teachers' abilities to alter their practices was detailed in an independent technical report written for the Ontario Ministry of Education (see: Vanderlee, Grierson, Gallagher, \& Mgombelo, 2006). Factors identified by observing teachers as contributing to the effectiveness of this initiative included the provision of believable, vicarious experiences; the demonstration teachers' exemplary mentoring skills; and the cohesion between the demonstration classroom initiative and other professional learning opportunities (Grierson \& Gallagher, 2009). Although these publications detailed the perspectives of observing teachers and the demonstration teachers, they did not document the perspectives of administrators involved in the implementation of this program. Moreover, while the importance of administrative leadership in engaging teachers in professional learning opportunities has been acknowledged (Fullan, 2006a; Mangin, 2007; Matsumara et al., 2009; Youngs, 2001), little if any research has explored the experiences of administrators involved in the implementation of school-based, system-wide professional learning initiatives such as those provided through this demonstration classroom program.

The purpose of the study described herein was to document the complexities of hosting a demonstration classroom site from the perspectives of school administrators involved in doing so. Specifically, the administrators elaborate on the impact of hosting the demonstration classroom initiative on the school community and the complexities of their interactions with the demonstration classroom mentor teachers, who as members of their teaching staff simultaneously held both site-based and system-wide responsibilities. Finally, the administrators offer recommendations to others interested in initiating or refining site-based, system-wide professional learning initiatives such as demonstration classroom professional development programs.

\section{Methodology}

In order to understand each administrator's experience with the demonstration classroom program, case study methods were adopted. Case studies are undertaken frequently when researchers want to derive in-depth understandings of a particular phenomenon that is unique or unusual (Creswell, 2002; Merriam, 2001; Yin, 2003). We believed that this research design would best illustrate the interconnectedness among the participants, as well as the complexities of their unique circumstances. Descriptions of the demonstration classroom program, the administrator participants, and their school contexts are provided next, followed by our data collection and analyses methods. 


\section{Context: Demonstration Classroom Professional Development Program}

The Demonstration Classroom Professional Development Program was funded in part by a grant from The Council of Ontario Directors of Education (CODE). In keeping with the objectives of this grant, the primary objective of the project was to promote school improvement through enhancing teachers' abilities to implement research-based programming as outlined within the Ministry of Education guides and reports (e.g., Ministry of Education of Ontario, 2003a; 2003b; 2005).

Upon approval of this grant application, the four demonstration classroom teachers were selected by the school board program officer. Each was selected for this role on the basis on their exemplary classroom teaching practices, together with their prior successful experience facilitating the professional growth of colleagues as a literacy coach during the year preceding the implementation of the demonstration classroom initiative. Importantly, each of these four teachers had accepted a full-time classroom teaching position at a district school for the ensuing school year, prior to the approval of this grant and development of this project. After they were selected as demonstration teachers, the administrators of their respective schools were "invited" to host the demonstration classrooms sites for the school board and asked to reduce the sitebased teaching responsibilities of the demonstration teachers from full-time to half-time (mornings only).

The specific teaching practices to be modeled within each of the demonstration classrooms were determined collaboratively by the curriculum department program officer, the three school board divisional consultants, and the four demonstration classroom teachers. This process was intended to ensure that observing teachers focused on the use of research-based approaches as advocated by the school board program department and the provincial Ministry of Education. Three divisional consultants were also actively involved in establishing the sitebased demonstration classrooms prior to the onset of observing teachers' visitations. Specifically, the consultants ensured that these classrooms were equipped with all recommended resources, and acted as coaches to the demonstration teachers, which assisted them in refining their exemplary practices to meet the needs of the targeted population of observing teachers.

Once the demonstration classroom learning environments were established, observing teachers were invited to visit one of these classrooms in groups of three or four. These visitation opportunities were to be booked in advance, three days each week between October and June, with the bookings arranged initially through the site-based school secretaries, and later through the demonstration teachers directly. Observing teachers were each encouraged to participate in a series of three visits, over the course of the school year, to the demonstration class that was most similar to their current teaching assignment. Each visit had a specific targeted focus, with the first visit focusing on observing the physical classroom set up, as well as effective classroom management strategies. The focus of second visit was to observe explicit instruction in action, particularly the demonstration teacher's use of modelling and integrated activities. The final observation focused on effective assessment, evaluation, and planning. Scheduling these three dispersed sessions, each several weeks after one another throughout the school year, was intended to provide the observing teachers with the time required to reflect and implement modifications to their own practices following each observation.

While each visitation took place for a full school day, only the mornings were spent observing in these classrooms, with the afternoons devoted to debriefing. During each afternoon 
debriefing session, the demonstration teachers used scripts prepared by the program department, to explore observing teachers' experiences and questions. The demonstration teachers also used these scripts to assist each participant in establishing SMART (specific, measurable, attainable, results-oriented, time-bound) goals for modifying their own practices following each observation session (Kelleher, 2003). A copy of each teacher participant's goal setting sheet, completed at the conclusion of each observation, was shared with both the administrator of the observing teacher's school site and the demonstration teacher for future follow up.

Throughout the duration of the demonstration classroom program, the three school board divisional consultants presented release-time Ministry of Education workshops and after-school workshops that focused on the practices modelled within the demonstration classroom sites. Furthermore, in attempts to foster on-going, site-based administrative support throughout the school district, the demonstration classroom initiative was discussed by the curriculum department program officer at each monthly meeting of school administrators throughout the school year. During these meetings all administrators were encouraged to discuss observing teachers' experiences and goals during their school-based monthly professional learning community meetings.

\section{Participants}

This qualitative study focused on the perspectives of administrators at each of the four demonstration classroom school sites and the perspective of the system-wide administrator responsible for this program, who was the curriculum department program officer. The five administrator participants included Matt, Roger, Chris, Pat, and Fran (pseudonyms). Matt was the administrator at the Grade 4/5 demonstration classroom site, located in a small rural town school. He had over two decades of experience as school administrator and was flexible in providing for the demonstration classroom's needs. Matt's school site was new and easily accommodated the space requirements of the demonstration classroom program (e.g., a room for the afternoon debriefing sessions, parking for observing teachers). His school employed 23 teachers who served over 430 students who attended Kindergarten through Grade 8.

Roger hosted the Grade 4 demonstration classroom in his school which was located in the suburbs of a medium-sized city. Educational administration was Roger's second career and he had less than 5 years experience in the role. Approximately 245 students attended Grades 4 through 8 at his school site that employed 14 teachers. Because Roger's school site was underutilized, he was able to allocate physical space to the demonstration classroom initiative with ease.

The Grade 2 demonstration classroom was located in an inner city school serving a transient student population; Chris was the administrator there. Chris was a novice administrator who was eager to allocate the available space in his school site to the demonstration classroom school board initiative. There were nine teachers employed at his school site who were responsible for teaching over 190 students in Grade Kindergarten through Grade 8.

Pat was the administrator of a school, located in the suburbs of a medium-sized city that hosted the Grade 7 demonstration classroom. She was a veteran administrator of a school that employed 16 teachers. Her school site served over 260 students who attended Kindergarten through Grade 8. Pat's school was at enrolment capacity and she had to creatively allocate space for the demonstration classroom program to operate. 
Finally, Fran, the system-wide, curriculum department program officer who was responsible for the development of the program was also included as a participant. Fran was a veteran elementary school administrator. In her role as a senior school board administrator, Fran was actively involved in selecting the demonstration classroom teachers with whom she also met weekly and co-participated in Ministry of Education workshops and conferences.

\section{Data Collection}

Data were collected at the end of the 9-month initiative, allowing participants the opportunity to reflect holistically on their experiences. Each of the four administrators at the demonstration school sites took part in a 1-hour, semi-structured individual interview during which they were asked to elaborate on how their site was chosen to host a demonstration classroom and reflect on the initial organizational elements. They were also asked about their ongoing facilitation of the demonstration classroom site, with attention to their administrative experiences during this site-based, system-wide initiative and how they supported their demonstration classroom teacher. Additionally, the curriculum department program officer participated in a 90-minute, semi-structured, individual interview. Questions focused on the organizational aspects of the inception and development of the demonstration classroom project, along with her administrative insights about the strengths and challenges of the initiative throughout the first year of operation. All interviews were audio-taped and transcribed and each participant was provided with a full transcription of their interview, as well as a copy of the researchers' interpretations of their insights for review, clarification, and verification of accuracy (i.e., member checks).

\section{Data Analyses}

Qualitative methods were used to analyze the participants' responses. More specifically, the interview data were analyzed through coding, categorizing, and identifying recurring themes as described by Creswell (2002) and Merriam (2001). Two researchers reviewed and coded all data independently, meeting subsequently to present and discuss their interpretations in order to arrive at a shared understanding of the results of this study.

\section{Findings}

Analysis of these five administrator participants' responses revealed the following three themes: (a) the need for advance planning, (b) the importance of consistency, and (c) the acknowledgment of the demonstration classroom teachers' dual roles and responsibilities. A detailed description of each theme is presented next together with documentary evidence.

\section{The Need for Advance Planning}

The demonstration classroom project received confirmation of provincial funding less than 3 months prior to the beginning of the school year. The short timelines required administrators to delineate quickly the implementation details of the proposed program. Consequently, as outlined by the program officer there was little time for consultation and ironing out the pragmatics of organizational elements such as the provision of administrative assistance for booking observing teachers' visits. These unforeseen organizational needs created stress for some administrators:

This is one of the lessons learned; you need to have a vision for this kind of project...A demonstration classroom should be something that you apply to have in your school...In 
getting this program up and running, the stress is not the 95\% you plan for, it's the 5\% you don't know about. (Program Officer, Fran interview, June 2006)

The four school-based administrators in this study hired the demonstration teachers with an implicit understanding that they would be regular, full-time staff members for the ensuing school year. There was no initial awareness that these former literacy coaches might be asked to assume system-level responsibilities, in addition to their school-based duties. Following the selection of these teachers as demonstration classroom teachers, each administrator was asked by the school board to support the implementation of a demonstration classroom within their school site. This request was honoured, although not always embraced at the outset of the program:

The way that we were selected to be a demonstration site was I already had the teacher hired as a full-time teacher for next year. Then the program came to fruition after I did my hiring. They [the board] really wanted her so they told me that I was a demonstration site...This was sort of the way that it happened at my school...I really wanted a consistent teacher [without system responsibilities]. So, that's where we started, that's not where we ended. (Administrator, Pat interview, June 2006)

After a period of time, all administrators supported this professional development program, believing that their school community would benefit from participating as a host site:

I was able to accommodate them [the board] and said, "Yes, you are welcome here, as a pilot site." I wanted the rewards of being a demonstration site and what comes along with it, more resources, accessibility to an excellent teacher, having staff close to it. (Administrator, Matt interview, June 2006)

However, the lack of advance planning created by delayed approval of funding for this initiative presented site administrators with some significant unanticipated challenges. The demonstration classroom teachers were "all thoroughbreds, had a strong work ethic...were generous with their time and resources, were really high achieving, and expected the best of everyone” (Program Officer, Fran interview, June 2006). The four demonstration teachers held classroom teaching responsibilities for the mornings only, with the afternoons devoted to debriefing with the observing teachers, at which time their classroom responsibilities were assumed by their teaching partners. As a result of their distinct strengths, one of the most difficult challenges for the school administrators was the hasty selection of compatible teaching partners for these highly skilled demonstration classroom teachers:

Finding someone appropriate for the other half of the day was difficult. All of the longterm occasional teachers had been hired. The only ones left were the ones that nobody else had recommended for a position. So that sort of put me into a sort of downward spiral. I was very concerned about getting somebody appropriate that would also be a good match for Barbara [demonstration classroom teacher]. Barbara has a very unique style and I needed somebody that would sort of go with her. (Administrator, Pat interview, June 2006)

Additionally, this program required the school site to provide a designated physical space for the debriefing sessions and sufficient parking for program participants. It was also necessary to have a school culture that would be accepting of the many visitors to the site throughout the duration of the school year. In some sites these elements were readily available and administrators provided abundant support: 
We had the room in the school to be able to host, so that it was not a stress on the school or even the people because this is an underutilized school. So this was a good fit for the system. (Administrator, Roger interview, June 2006)

All the physical things such as directions to the school, parking, start times, and bell schedules for recess times were information that we included on a cover page. This was available to all observing teachers. We provided this information on all of the key resources. (Administrator, Chris interview, June 2006)

However, in other sites, initially these issues were not resolved satisfactorily and challenging administrative details included resources, materials, and coffee fund money. In these circumstances the system-wide administrator provided the leadership required to resolve these dilemmas. The curriculum department program officer provided, "the administrative support needed, the assurance that all the technical things would be taken care of and a guarantee that hosting a demonstration classroom wasn't going to be intrusive into their school communities” (Administrator, Chris interview, June 2006).

\section{The Importance of Consistency}

Administrators perceived that the demonstration program was most successful at the school level when there was consistency between the teaching style and approaches of the demonstration classroom teacher and their $1 / 2$-day teaching partner. Lack of consistency was noted as a concern expressed by parents in one community:

I think what I did not anticipate was opposition from the parent community. But because they were dealing with two teachers with very different styles there was a unique problem...Y You need to have the same kind of exemplary teacher [as the partner for a demonstration teacher]. You need to have that balance so that students would come in and wouldn't see the differences. (Administrator, Roger interview, June 2006)

As well, administrators noted that it was important to have consistency between the demonstration classroom teacher and the other site-based teaching staff members with respect to expectations, programming, and the teaching resources provided. As model classrooms, the demonstration rooms were resource rich, with all required materials provided by the district program department. In some cases, this caused other site-based teaching staff to request additional resources in order to provide similar programs. Additionally, in some instances other teachers on staff at the demonstration classroom sites expressed initial concern about the potential to be compared negatively to the exemplary demonstration teacher:

I explained it [the demonstration classroom] to my teaching staff and told them the advantages of it and some of the workings of it. I told them that there would be minimal impact on them. In the beginning, there was that feeling of "who is this person?" "Is she going to make us look bad?" In the beginning there were comments such as, "How come she's got all of those resources and we don't have that?” Since I'm teaching across the hallway from her [the demonstration teacher], I wonder if I will be compared to her. (Administrator, Matt interview, June 2006)

While acknowledging the beneficial effects to their school sites of enhanced teacher knowledge, and the benefits to students of effective instructional practices, the provision of resources that other site-based teachers required to implement similar programming was an 
unanticipated school expense. However, whenever possible administrators provided such resource equity across their school sites:

Big money went into that demonstration classroom. It was nice because it had a ripple effect, but it cost me money in the end. It cost me money because the demonstration teacher had a listening centre and I had to buy three more listening centres [for other sitebased classroom teachers]. She had a carpet and then all the intermediate teachers went with carpets. This is money I did not mind spending but it did have an impact on my budget because what they saw in her demonstration classroom, they all wanted. (Administrator, Pat interview, June 2006)

Additionally, many administrators noted the importance of clearly delineating ownership of the resources that were allocated to their demonstration classrooms should the program be discontinued. The administrators noted that these resources should become the physical property of the host school sites in order to sustain the programs provided to students in their schools:

The board was very generous. The demonstration classrooms had laptops, LCD projectors, special desks, manipulatives. They [the board] made the promise to me that whatever we throw into this demonstration classroom belongs to your school. If the program discontinues after a year, this belongs to your school. (Administrator, Pat interview, June 2006)

Indeed, to promote sustainability, the demonstration classroom resources, materials, and equipment became the physical property of the host school site.

\section{Acknowledging Demonstration Classroom Teachers' Dual Roles and Responsibilities}

All administrators perceived that the demonstration classroom teachers were overloaded with responsibilities uncommon for classroom teachers and required support, rather than additional demands:

I would never do that job; it was very onerous. The demonstration classroom teacher has all of the 1/2-day responsibilities of the homeroom teacher and then on top of that, all the responsibilities of a demonstration teacher, and then on top of that, all the responsibilities of what goes with it, such as connections to the board and Ministry. I think that it is hard to get people to do that. (Administrator, Matt interview, June 2006)

Particularly salient was administrators' acknowledgment of the difficulties of the dual roles and responsibilities held by the demonstration teachers. Consequently, these administrators had to be flexible in their expectations related to the demonstration classroom teachers' contributions to the school community through extra-curricular responsibilities such as coaching.

A demonstration teacher cannot be a fully participating staff member. (Administrator, Pat interview, June 2006)

Dee [demonstration classroom teacher] was into volleyball, and there were other things that she perhaps could have offered the kids [if she were not also a demonstration teacher]...So that was one less [coach], I did not anticipate that and it was a hardship on the school. (Administrator, Roger interview, June 2006)

This complexity associated with the demonstration classroom teacher's dual role required the administrators to be adaptable and work towards meeting the needs of their local school community, while not overburdening the demonstration teachers and other site-based staff 
members. In all cases, the relationships between the administrators, demonstration classroom teachers, and other teaching staff members were dynamic:

Other site-based teachers saw the demonstration classroom teacher as someone who is not threatening, intimidating, or going to make them look bad. It just reinforced the good things that they're doing already. They started being open to learning from her [demonstration teacher], talking to her and going to her for advice. I saw teachers in there before school, after school, and engaging in impromptu dialogue about good instructional strategies...I've found that teachers didn't feel threatened and could go to her for advice and direction. She was an identified teacher who had definite strengths in literacy. So, instead of coming to me, and I don't have all the answers, it was nice to have somebody else who could take over for me. The combination of her personality and the leadership style in curriculum, seemed to work with my staff. (Administrator, Matt interview, June 2006)

There are challenges associated with the demands of the demonstration classroom position. Dee did a good job working with the other junior teachers. Dee would free herself up and do some in-school, in-servicing. She would link everything to our school improvement plan such as mentoring others on the administration of an assessment. (Administrator, Roger interview, June 2006)

Within our school-based professional learning community, we did a book study this year. Barbara [demonstration classroom teacher] was very good at creating professional dialogue. She modelled a lot of it at the beginning, and then it sort of took on a life of its own. Her expectations were high and that raised the bar for all of us. Barbara has taught the staff how to use the resources effectively in a classroom setting and how to integrate curriculum across all strands. She's been an instructional model in the school. She's had an amazing impact at this site. (Administrator, Pat interview, June 2006)

Administrators all noted their demonstration teachers' exemplary practices, as well as, their outstanding efforts, abilities, and commitment to the professional development of their peers:

She, actually, not only mentored observing teachers, but the teacher in the afternoon that replaced her classroom duties was a new teacher. It was exceptional for that afternoon teacher to be mentored by the demonstration teacher. (Administrator, Matt interview, June 2006)

Some administrators stated that they needed to provide unique forms of support to their demonstration teacher as a function of their complex roles mentoring teachers from across the system who had a mosaic of needs:

[The demonstration teacher shared how] observing teachers made comments that they tried certain suggestions in their classes and concluded that it doesn't work. They [observing teachers] were reluctant to change. I think what she [demonstration teacher] experienced was how static some teachers can be. So [helping her to deal with] this took a lot of encouragement on my part. (Administrator, Chris interview, June 2006) 
While most administrators perceived there was a cost to their school because of the demonstration teachers' decreased community involvement, all believed that the program was very beneficial to the school and system at large.

You have to look at how the demonstration classroom teachers interact with the community because of the time constraints. I had to understand that she was a teacher who was giving back to the system and this was taking away time from our school community. Of course we only had that wonderful teacher for half the day. I discussed this with the demonstration classroom teacher to make her aware of the fact that I would not try to put more on her plate. It was costly for the site, but a great benefit for the system. (Administrator, Roger interview, June 2006)

The perceived benefits for observing teachers and the school board as a whole were echoed in the concluding comments of Fran, the Program Officer, "The program has given [teachers] the foundation. They've had the opportunity to see theory put into practice; but we can't stop, we have to keep going. Principals have asked repeatedly that we provide this opportunity again for their teachers” (June 2006).

However, there were requests for both follow-up literacy coaching and the demonstration classroom program and regrettably, budgetary constraints rendered the provision of both impossible. At the end of the 1-year demonstration classroom program, the school board determined that a financially prudent and professionally effective follow-up learning initiative would be individualized teacher coaching. Consequently, the four demonstration teachers transitioned to the role of literacy coaches who provided classroom-based support to teachers throughout the school district.

\section{Discussion}

The demonstration classroom program was responsive to the mandate that the professional development of teachers should improve their practice and have a positive impact on student learning (Grierson \& Gallagher, 2009). This type of professional development cannot happen in a vacuum because schools are dynamic systems where students, teachers, school-based administrators, and senior school-board administrators interact and function to meet a mosaic of needs.

A systemic change framework (Ferguson et al., 2001) is appropriately applied to the demonstration classroom program to elucidate the interplay of actions among the district, school organization, teaching professionals, and students that contributed to change in teachers' practices. In educational settings, systemic change and improvement focused on student learning is possible when the actions of these interdependent components are coherently aligned and integrated (Fullen, 2001; Hargreaves, Earl, Moore, \& Manning, 2001). Researchers are, then, in a position to explore the actions of components (i.e., administrators) and identify productive functions and constraints to systemic change.

The administrators at these demonstration classroom sites hosted an innovative program of professional development that had a focus on teaching and learning that was systemic; it was consistently supported by other administrators and other school board professional development initiatives (Leithwood, Fullan, \& Watson, 2003). These components are consistent with the attributes that are cited as necessary conditions for school effectiveness (Leithwood et al., 2003). Each of the administrators at the demonstration sites had the governance to provide opportunities 
to build teacher capacity and act in ways that would potentially enhance the learning of all students (Newmann et al., 2000; Youngs, 2001).

Leadership can have a significant impact on students' learning through supporting and enhancing teachers' abilities to help students (Leithwood et al., 2003). To profile effective leadership at the school level, Leithwood and Riehl (2003) offer some research-based commonalities of successful administrators. These characteristics should be considered as prerequisites for administrators who wish to serve as hosts for site-based and/or system-wide professional development programs. Leaders should establish conditions for their staff to be effective, work with their staff to achieve shared goals, attempt to develop the individual human resources, and build collaborative learning communities in their schools. Effective school leadership is dedicated to facilitating a learning community that focuses on energizing people to make good decisions and improve their practices (Mintzberg, 2004). Further, successful school leaders have a shared vision and high expectations for teachers' practice, provide teachers with professional stimulation, and promote collaborative structures and cultures (Leithwood, Seashore, Anderson, \& Wahlstrom, 2004). All administrators profiled herein exhibited these attributes, despite the constraints created by the, at times, competing demands of simultaneously meeting the needs of their school sites and those of their school board.

The administrators at these demonstration classroom sites lived with tensions exerted between their responsibility to the system (i.e., their school board) and their responsibility to their school site. These administrators initially selected exemplary teachers to "raise the bar" in their own schools, only to later learn that they would be relinquishing half of theses educators' time to system-wide duties. Contemporary administrators carry a weighty responsibility to support what is termed, tri-level systemic change (Fullan et al., 2006). This involves simultaneously building the alignment of goals, purpose, and capacity at the provincial, board, and school-based levels. In this fashion, capacity building is a process of transformation and effective leadership is an integral component in that process. "Within the school, then, the role of leadership is to help provide the focus and an expert support system for all teachers with an emphasis on what is needed to personalize each classroom with greater instructional precision" (Fullan et al., 2006, p. 96). This study illustrates how effective administrators at demonstration classroom sites are well-positioned to do this.

The support and leadership of administrators in this school-based, system-wide professional learning initiative was integral to engaging teachers in the process of professional growth. Through validating the efficacy of this professional development initiative and regarding the demonstration classroom teachers as expert mentors, these administrators enhanced observing teachers' receptivity to change (Matsumara et al., 2009). In exhibiting flexibility and reducing the barriers to teachers' professional learning (e.g., providing space, creating a climate receptive to visitors) these administrators sent an implicit message to teachers system-wide that the demonstration classroom program they were engaging in was a valuable professional development activity (Mangin, 2007). Through leading by example, these administrators enhanced teachers' receptivity to professional learning throughout the school district (Matsumara et al., 2009).

The demonstration classroom program administrators fulfilled a vital role in the implementation of this program and also in delineating future directions for teachers' professional learning across this school board. Administrative recommendations for the next steps at the conclusion of the demonstration program included the provision of follow-up, site- 
based coaching for observing teachers to further enhance their abilities to implement the strategies and approaches that were witnessed in the demonstration classroom sites. "Literacy educators are the bridges. They can go into a classroom, assist in the set-up of the environment, and actually make a difference" (Administrator, Roger interview, June 2006). It was cost prohibitive for the school board to provide both demonstration classrooms and literacy coaching. In response to administrators' and observing teachers' requests to do so, this board implemented a follow-up program of site-based literacy coaching intended to provide classroom-based support and further foster the professional growth of observing teachers (Grierson \& Gallagher, 2009).

This transition from the professional learning context of demonstration classrooms to site-based literacy coaching has laid a strong foundation for teachers' professional growth (Grierson \& Gallagher, 2009). The demonstration program created momentum for change and provided, as an initial basis for teachers' ongoing professional development, the bridges between theory and practice (Grierson \& Gallagher, 2009). The administrators profiled in this paper provided the essential footings for these bridges and the lessons they learned in implementing this demonstration classroom program.

\section{Educational Significance}

Demonstration classroom professional development programs hold the potential to enhance teacher participants’ abilities to implement responsive programs (Grierson \& Gallagher, 2009). However, this study documented that effective administrative implementation of such programs requires advance planning, consistency, communication, and flexibility. Through the hindsight of this group of school administrators, others may be able to better plan to simultaneously meet the diverse needs of their school district and their individual school communities, as they embark on the implementation of site-based, system-wide professional learning initiatives in their attempts to build systemic capacity for educational improvement. 


\section{References}

Butler, D. L., Lauscher, H. N., Javis-Selinger, S., \& Beckingham, B. (2004). Collaboration and self-regulation in teachers' professional development. Teaching and Teacher Education, 20(5), 435-455.

Creswell, J. W. (2002). Educational research: Planning, conducting, and evaluating quantitative and qualitative research. Upper Saddle River, NJ: Merrill Prentice Hall.

Cochran-Smith, M., \& Lytle, S. L. (1999). Relationships of knowledge and practice: Teacher learning communities. Review of Research in Education, 24, 249-305.

Dufour, R., \& Eaker, R. (1998). Professional learning communities at work: Best practices for enhancing student achievement. Bloomington, IN: National Educational Service.

Elmore, R. F. (2004). School reform from the inside out: Policy, practice and performance. Cambridge, MA: Harvard University Press.

Ferguson, D., Kozleski, E., \& Smith, A. (2001). On transformed, inclusive schools: A framework to guide fundamental change in urban schools. Denver, CO: The National Institute for Urban School Reform.

Fullen, M. (2001). The three stories of education reform. Phi Delta Kappan, 81, 51-84.

Fullan, M. (2006a). Leading professional learning. The School Administrator, 10(63), 10-14.

Fullan, M. (2006b). Quality leadership: Quality learning. Paper prepared for the Irish Primary Principals’ Network.

Fullan, M., Hill, P., \& Crevola, C. (2006). Breakthrough. Thousand Oaks, CA: Corwin Press.

Grierson, A. L., \& Gallagher, T. L. (2009). Seeing is believing: Creating a catalyst for teacher change through a demonstration classroom professional development initiative. Professional Development in Education, 35(4), 567-584.

Guskey, T. R. (2002). Professional development and teacher change. Teachers and Teaching: Theory and Practice, 8 (3/4), 381-391.

Guskey, T. R. (2003). Analyzing lists of the characteristics of effective professional development to promote visionary leadership. NASSP Bulletin, 87 (637). 4-20.

Hargreaves, A., Earl, L., Moore, S., \& Manning, S. (2001). Learning to change: Teaching beyond subjects and standards. San Francisco, CA: Jossey-Bass.

Kelleher, J. (2003). A model for assessment driven professional development. Phi Delta Kappan, 84(10), 751-756.

Leithwood, K., Fullan, M., \& Watson, N. (2003). The schools we need: A new blueprint for Ontario. Toronto, ON: OISE/University of Toronto Press.

Leithwood, K., \& Riehl, C. (2003). What we know about effective school leadership. Philadelphia, PA: Laboratory for Student Success, Temple University.

Leithwood, K., Seashore, L., Anderson, S., \& Wahlstrom, K. (2004). How leadership influences student learning. New York, NY: Wallace Foundation. 
Lyons, C. A., \& Pinnell, G. S. (2001). Systems for change in literacy education: A guide to professional development. Portsmouth, NH: Heinemann.

Mangin, M. M. (2007). Facilitating elementary principals' support for instructional teacher leadership. Educational Administration Quarterly, 43(3), 319-357.

Matsumara, L. C., Sartoris, M., Bickel, D., \& Garnier, H. E. (2009). Leadership for literacy coaching: The principal's role in launching a new coaching program. Educational Administration Quarterly, 45(5), 655-693.

Merriam, S.B. (2001). Qualitative research and case study applications in education. Revised and expanded from case study research in education ( $2^{\text {nd }}$ ed.). San Francisco: Jossey-Bass.

Ministry of Education of Ontario (2003a). Early reading strategy: The report of the expert panel on early reading in Ontario. Toronto, Canada: Queen's Printer for Ontario.

Ministry of Education of Ontario (2003b). A guide to effective instruction in reading, Kindergarten to Grade 3. Toronto, Canada: Queen’s Printer for Ontario.

Ministry of Education of Ontario (2005). Education for all: The report of the expert panel on literacy and numeracy instruction for students with special education needs, Kindergarten to Grade 6. Toronto, Canada: Queen's Printer for Ontario.

Mintzberg, H. (2004). Managers not MBAs. San Francisco, CA: Berrett-Koehler Publishers.

Newmann, F. M., King, M. B., \& Youngs, P. (2000). Professional development that addresses school capacity: Lessons from urban elementary schools. American Journal of Education, 108(4), 259-299.

Poglinco, S., Bach, A., Hovde, K., Rosenblum, S., Saunders, M., \& Supovitz, J. (2003). The heart of the matter: The coaching model in America's choice schools. University of Pennsylvania, Graduate School of Education: Consortium for Policy Research in Education.

Sparks, D., \& Loucks-Horsley, S., (1990). Models of staff development. In R. Houston (Ed.), Handbook of Research on Teacher Education, ( $3^{\text {rd }}$ ed., pp. 234-250). New York, NY: MacMillan Publishing Company.

Vanderlee, M. L., Grierson, A. L., Gallagher, T. L., \& Mgombelo, J. (2006). Final report for The Literacy and Numeracy Secretariat: Evaluation of the XXXX School Board's demonstration classroom project (Tech. Rep. No. 1). St. Catharines, ON: Brock University, Faculty of Education.

Walpole, S., \& McKenna, M. C. (2004). The literacy coach's handbook: A guide to researchbased practice. New York: Guilford Press.

Yin, R. K. (2003). Case study research: Design and methods (3rd ed.). Thousand Oaks, CA: Sage Publications.

Youngs, P. (2001). District and State Policy Influences on Professional Development and School Capacity. Educational Policy, 15(2), 278-301. 